\title{
Geçmişten Günümüze Yüksek Fruktozlu Mısır Şurubu ve Sağlık Etkileri Üzerine Bir Derleme
}

\author{
High Fructose Corn Syrup From Past to Present and A Review on Health Effects
}

\author{
Neşe Aşıc1, Gökhan Oturak, Hasan Çetin Ekerbiçer \\ Sakarya Üniversitesi Tip Fakültesi, Halk Sağlı̆̆ı AD, Sakarya, Türkiye
}

\begin{tabular}{|c|}
\hline $\begin{array}{l}\text { Yazışma Adresi / Correspondence: } \\
\text { Neșe Aşı1cı }\end{array}$ \\
\hline $\begin{array}{l}\text { Sakarya Üniversitesi Eğitim ve Araştırma Hastanesi Merkez Kampüsü / Sakarya } \\
\begin{array}{ll}T:+905057677768 & \text { E-mail: nesea@sakarya.edu.tr }\end{array}\end{array}$ \\
\hline Geliş Tarihi / Received : 02.06.2020 Kabul Tarihi / Accepted : 29.06.2020 \\
\hline Orcid: \\
\hline Neşe Aşıcı ORCID: https://orcid.org/0000-0003-0266-6845 \\
\hline Gökhan Oturak ORCID: https://orcid.org/0000-0003-1608-8433 \\
\hline Hasan Cetin Ekerbicer ORCID: https://orcid.org/0000-0003-0064-3893 \\
\hline
\end{tabular}

$\ddot{\mathrm{O} z}$

Yüksek Fruktozlu Mısır Şurubu (YFMȘ), günümüzde en çok kullanılan ve hakkında en çok tartıșlan gıda katkı maddelerinden biridir. Maliyet ucuzluğu, kullanım kolaylığı, sakkaroza göre daha lezzetli olması, tatllık, kıvam ve renk sağlama avantajları neticesinde 1970’li ylllardan sonra gida endüstrisinde sakkarozun en büyük rakibi olmuş, 2004 yllına kadar popülaritesi artmış bir üründür. YFMŞnin tüketiminin arttığı yllların, obezite prevalansında artı̧̧ıın yaşandığı döneme denk gelmesi, YFMŞ ve sağı̆ı üzerine etkileriyle ilgili çalışmaların hız kazanmasına neden olmuștur. YFMŞ özellikle içeriğindeki fruktozun, glukozdan farklı metabolik yolaklar kullanarak vücutta metabolize olması ve bunun neticesinde farkl metabolik etkileri bu endișelerin ana nedenlerinden bazilarıdır. Bu derlemeyi hazırlama amacımız, geçmișten günümüze hala eleștirilen YFMŞ hakkında güncel bilgiler sunmak, özellikle sağlıklı tüketici bilincini geliştirmek amacıyla YFMŞ ve olası olumsuz etkileri hakkında tüketicileri bilgilendirmektir.

Anahtar Yüksek Fruktozlu Mısır Şurubu; sakkaroz; fruktoz; tatlandırıcı; sağılklı diyet

High fructose corn syrup (HFCS) is one of the most commonly used and most contraversial food additives. Cost-effectivity, usage ease, relatively better taste compared to sucrose, sweetness, consistence and colour advantages made it the biggest rival of sucrose in the food industry after 1970s and it held its popularity up to 2004. Because the years which HFCS usage have increased, paralleled the increase in obesity, studies focusing on the effects of HFCS on the health have also increased.

YFMS, especially the metabolism of fructose in the body by using different metabolic pathways than glucose and consequently different metabolic effects are some of the main causes of these concerns. The reason we prepare this review is to provide up to date information on the highly critisized HFCS, develop a healthy consumer opinion and inform the consumers on HFCS and possible negative consequences on the health. 


\section{GIIRIŞ}

Yüksek Fruktozlu Mısır Şurubu (YFMŞ), gıda endüstrisi tarafından, mısır nişastasından üretilen sıvı yapıda glukoz-fruktoz içeren bir tatlandırıcıdır. ${ }^{1}$ Sakkaroz, şeker kamışı ve şeker pancarı özünden doğrudan çıkarılan doğal bir ürün olmasına rağmen, YFMŞ’nin oluşumu doğal değildir. ${ }^{2}$ Sakkarozun yapısındaki fruktoz ve glukozun her ikiside bitkilerde bulunduğu haliyle doğal yapıda iken, YFMŞ’nin içeriğindeki fruktoz modifiye yapıdadır. ${ }^{3}$

1960 'lı yıllarda sakkaroz üretiminde yaşanan aksaklıklar ve fiyat artı̧̧ı neticesinde gıda endüstrisine giren YFMŞ, 1980 'li yıllarda artık bir çok içecek ve yiyecek maddesinin ana tatlandırıcısı konumuna gelmiştir., ${ }^{4,5}$ Özellikle YFMŞ uygun fiyatı, sıvı formda oluşu, koruyuculuk özelliği ve yoğun tatlllığı nedeniyle çoğu gida şirketi tarafından tercih edilen bir kalorili tatlandırıcıdır. ${ }^{6}$

Yüksek fruktozlu mısır şurubu pazarı, yiyecek, içecek ve ilaç endüstrisine ayrılmaktadır. Yiyecek ve içecek endüstrisi pişirme, konserve, tahıl ürünleri, süt ürünleri, gazlı alkolsüz içecekler, çeşniler, şekerlemeler, dondurma ve tatlılar olarak alt bölümlere ayrılmıştır ve bu pazarda payı en çok olan 2 ülke Kuzey Amerika ve Japonyadır.7 Amerika Birleşik Devletlerinde (ABD) YFMŞ’nin (High Fructose Corn Syrup-HFCS) elde edildiği ana bileşen misır iken , Avrupa Birliği (AB) ülkelerinde YFMŞ’nin karşıllı̆̆ı olan izogukozun ana bileşeni mısır, patates ve buğdaydır.,

YFMŞnin 1980'li ylllarda popülaritesi , 2004 yllında Bray ve ark.'larının yaptığı çalışma neticesinde ortaya çıkan YFMŞ ve obezite arasındaki nedensel bağlantı iddiası ile tehlikeye girmeye başlamıştır. Bray ve ark.'1 özellikle eklenmiş şekerlerin büyük bir yüzdesini oluşturan YFMŞ’nin piyasaya çıkmasıyla, obezite prevalansı arasındaki ilişkiye dikkat çekmiştir. $^{2}$

YFMŞ’nin sağllk üzerindeki olumsuz etkilerine dair endişeler genellikle içeriğindeki fruktozun iştah ve metabolizma üzerine olan etkilerinden kaynaklanmaktadır. ${ }^{10}$
Özellikle 2004 yılından sonra YFMŞ gibi şekerle tatlandırılmış içecekler ile obezite, metabolik sendrom, kardiyovasküler hastalıklar, kan basıncında artış, inflamasyon belirteçlerinde ve trigliserit seviyelerinde artış arasında ilişki olduğunu gösteren çok sayıda çalışma mevcuttur. ${ }^{11-14}$

YFMŞ’nin diğer şekerlerden olası daha olumsuz etkileri ile ilgili tartışmalar devam etmektedir. Food and Drug Administration (FDA), 1983 yılında YFMŞ’yi güvenli olarak listelemiş (Genellikle Güvenli Olarak Tanınır / Generally Recognized as Safe-GRAS) ve 1996'da bu kararı yeniden teyit etmiştir. ${ }^{15}$ Her ne kadar FDA , YFMŞ'yi GRAS kategorisine almış olsada diğer ilave şekerlerde olduğu gibi YFMŞ’ninde başta diyabet olmak üzere farklı sağlık sorunlarına yol açabileceğini vurgulamıştır. ${ }^{15}$

\section{ŞEKER}

Şeker (karbonhidrat) gıda maddelerinde tatlılığı Sağlayan bir moleküldür. Doğal olarak oluşan şeker (herhangi bir işlem görmeden kendiliğinden oluşan, masada eklenmeyen) ve herhangi bir yiyeceğe eklenen şeker olarak 2 gruba ayrillir. $^{2}$

Glukoz, çoğu karbonhidratın yapı taşı olan en basit şekerlerden birisidir ve vücuttaki enerji üretimi için birincil metabolittir. ${ }^{16}$ Diğer bir monosakkarit olan fruktoz, 2. karbonunda bir keto yan dalı bulunması dışında yapısal olarak glukoza benzer. ${ }^{17}$ Doğada genellikle bu iki şeker disakkarit yapıdaki sukrozu (sakkaroz) oluşturarak yiyeceklerin doğal tatlılığına katkıda bulunurlar. Fruktozun tatlılık oranı yaklaşık olarak glukoza göre 2 kat, sukroza göre ise 1,5 kat fazladır. ${ }^{18}$ Hammaddeye göre tatlılık oranının yüksekliği nedeniyle sakkaroz ve fruktoz gıda endüstrisinde tatland1rıcı olarak oldukça fazla kullanılır. ${ }^{19,20}$ Fruktozun en yaygın kullanılan formu ticari amaçla tatlandırıcı olarak kullanılan YFMŞ formudur. ${ }^{12}$ Sakkaroz; şeker pancarı ya da şeker kamışından elde edilen bir disakkaritir ve $\% 50$ fruktoz ve $\% 50$ glukozun birbirlerine kovalent bağlanmasıyla oluşur. ${ }^{21}$ 
Dünya Sağlık Örgütü’nün (DSÖ) önerdiği şeker tüketim miktarı, günlük kalorinin \%10'undan az ve tercihen $\% 5$ 'in altında olmalısıdır. ${ }^{22}$ Günde 2000 kalori alan bir kişinin tüketeceği şeker miktarı 50 gramı geçmemelidir. Daha iyi anlaşılabilmesi açısından örnek vermek gerekirse yaklaşık 280 cc'lik 1 kutu kola 39 gram şeker içermektedir. ${ }^{23}$

\section{TATLANDIRICI}

Tatlandırıcılar, ilk keşfedildiklerinde lüks gıda maddesi olarak toplumun zengin kesimi tarafından tüketilirlerken son üç yüz yılda bilimsel tarımda yaşanan ilerlemeler neticesinde her kesimden insanın diyetinin bir parçası haline gelmiştir. $^{4}$

Tatlandırıcıların geçmişine baktığımızda ilk olarak sakkaroz işlenmiş gıdalarda ve içeceklerde tatlandırıcı olarak kullanılmaya başlanmıştır. Son 30 yılda YFMŞ birçok üründe kullanılan tatlandırıcı olarak sakkarozun birincilik tacını elinden almıştır.

Tatlandırıcılar kalorili ve kalorili olmayan tatlandırıcılar olmak üzere 2 gruba ayrılırlar. ${ }^{24}$ Kalorili tatlandırıcılar sakkaroz ya da nişasta bazlı olabilirler. Sakkaroz kökenliler, pancar ve kamıştan, nişasta kökenliler mısır, buğday ve patatesten üretilmektedirler. ${ }^{24}$ Çoğu kalorili tatlandırıcı fruktoz içerir ve 1 gram başına 4 kcal sağlar. ${ }^{10}$ Kalorili tatlandırıcıların bir kısmının kalori miktarı daha düşük olup bu gruba sorbitol, mannitol, ksilitol, eritritol, izomalt, laktitol girer. Bunlar 1 gr başına 0.2-3 kcal sağlarlar. ${ }^{25}$

Kalorili olmayan tatlandırıcılar; sakarin, siklamat, aspartam, asesülfam potasyum, neotam ve sukralozdur. Bunlardan bir tek aspartam 1 gr başına 4 kcal sağlar ve diğerlerinin kalori değeri yoktur. ${ }^{10,26}$ Günümüzde en yaygın kullanılan kalorili 2 tatlandırıcı YFMŞ ve sakkarozdur.

\section{YFMŞ}

YFMŞ; gıda endüstrisi tarafından, mısır nişastasının kimyasal ve 3 farklı enzimin rol aldığı enzimatik teknikler kullanılarak çözündürülmesi sonucu mısır şurubu, mı- sır şurubunun izomerizasyon, sıvılaştırma ve parçalama aşamalarından geçirilmesiyle oluşturulan sıvı yapıda glukoz-fruktoz içerikli bir tatlandırıcıdır. ${ }^{1,8,26}$

YFMŞ ürünleri fruktoz içeriğine göre sinıflandirılmaktadır. YFMŞ'de glukoz ve fruktozun serbest formlarda bulunması neticesinde fruktoz-glukoz oranları değiştirilebilir ve farklı formülasyonlar oluşturulabilir.. ${ }^{27,28}$ Üretim aşamasında ilk olarak YFMŞ-42 üretilir, YFMŞ-42 fruktozu tutan kolonlardan geçirildikten sonra YFMŞ-90 üretilir, YFMŞ-90'nın YFMŞ-42 ile karıştırılmasıyla YFMŞ-55 üretilir. ${ }^{29}$ YMFŞ-42 yaklaşık \% 42 fruktoz, \% 53 glukoz, YMFŞ-55 yaklaşık \% 55 fruktoz, \% 41 glukoz, YMFŞ-90 ise yaklaşık \%90 fruktoz, $\% 9$ glukoz içermektedir. ${ }^{24}$

Sakkarozun ikamesi denilince daha çok YFMŞ- 55 bilinmektedir. YFMŞ- 55 en yaygın kullanılan formdur ve $\% 50$ fruktoz ve \%50 glukoz içeren sofra şekerine benzerdir. Sakkarozdan en önemli farkı YFMŞ’nin \%24 su içeriğiyle sıvı formda olması, sakkarozun ise kuru ve granül yapıda olmasıdır. ${ }^{30}$

YFMŞ-42, sakkarozdan daha az fruktoz miktarına sahip olduğu için daha az tatlıdır ve fırınlanmış ürünlerde, konserve meyvelerde, soslarda, baharatlarda, süt ürünlerinde, YFMŞ-55 ise tatlılık açısından sakkaroz ile aynı tatlılık seviyesinde olduğu için gazlı alkolsüz içeçeklerde, dondurma ve dondurulmuş tatlılarda tatlandırıcı olarak kullanılmaktadır. ${ }^{24,31}$ YFMŞ-90 en konsantre formdur ve özel uygulamalarda kullanılır. ${ }^{26}$

\section{I -YFMŞ’nin Tarihçesi:}

Tarihte mısır şurubu, ilk defa 1864 yılında Birlik Şeker Şirketi (Union Sugar Company) tarafından mısır nişastasından üretilmiş olup, 1950'li yılların sonunda Clinton Mısır İşleme Şirketi (Clinton Corn Processing Campany) mikrobiyal enzimleri kullanarak misır glukozunu fruktoza çevirmiş, 1960’lı yılların sonlarında Japon Endüstriyel Bilim ve Teknoloji Ajansı'ndan bilim adamı Yoshiyuki Takasaki, Streptomyces sp.den türetilen ısıya dayanıklı bir 
glikoz izomerazı izole ederek mısır nişastasından YFMŞ’yi geliştiren ilk kişi olmuştur. ${ }^{21}$

YFMŞ, 1960'lı y1llarda yaşanan sakkaroz üretimindeki aksaklıklar ve buna bağlı gelişen fiyat artışından dolayı sakkaroza alternatif olarak geliştirilmiş bir tatlandırıcıdır ve 1960'lı yılların sonlarına doğru yiyecek ve içeçek endüstrisine girmiş, 1974 yılında yaşanan şeker pazarı istikrarsızlı̆̆ı neticesinde 1980'li yıllarda içecek endüstrisinde kullanımı hız kazanmıştır., ${ }^{4,5}$

YFMŞ, 1967 yılında YFMŞ-42 (1. Jenerasyon) olarak üretilmeye başlanmış, 1977 yılında YFMŞ-55 (2.jenerasyon) piyasaya sürülerek, alkolsüz içeçecekler ve unlu mamüller, meyve konserveleri, sütlü mamüller, reçel ve jöle başta olmak üzere bir çok gıda maddesinde tatlandırıcı olarak kullanılmaya başlanmıştır. ${ }^{2,26}$

\section{II-YFMŞ Neden Sakkarozun Yerini Almıştır?}

YFMŞ, sakkaroza göre farklı özelliklere sahiptir. Öncelikli olarak maliyeti ucuzdur ve sakkarozdan daha tatlıdır. ${ }^{32}$ YFMŞ; sakkaroza göre daha lezzetli, taze, kararlı, doku, kıvam ve renk sağlama açısından avantajlıdır. ${ }^{33}$ Eklendiği gıdanın tadını güçlendirir ve gıdadaki diğer tatların daha net algılanmasını sağlar, ayrıca nem kontrolünün gelişmiş olması ve mikrobiyal bozulma ihtimalinin az olması nedeniyle gidanın tazeliğini korur ve raf ömrünü uzatır. ${ }^{10,34}$

YFMŞ'nin sıvı formda olması, transportunu kolaylaştırır ve granüle sakkarozdan daha iyi karıştırlmasını sağlar ve ayrıca süt ürünlerinde buzun kristalleşme hızı üzerinde güçlü bir etkisi vardır. ${ }^{7}$ YFMŞ sıvı tatlandırıcı olarak hem fermente hem de fermente olmayan unlu mamüller için uygundur. Sakkaroz ile karşılaştırıldığında aynı lezzet ve hacim ve daha kısa sürede dayanıklılık sağlar. ${ }^{19}$

\section{III-YFMŞ İçeren Ürünler $2,3,26,31,35$}

Kalorili tatlandırıcılar içeren tüm gıdalarda hemen hemen YFMŞ bulunmakta olup bu gıdaların başlıcaları;

- meşrubatlar,
- meyveli içecekler,

- sodalı içecekler,

- meyve şekerlemesi,

- meyve konservesi,

- aromalı süt,

- dondurma,

- dondurulmuş tatlilar,

- bisküvi, kurabiye, ekmek, gevrek gibi hamur ürünleri,

- reçel ve jöleler,

- yemeklere katılan soslar ve çeşniler,

- pişirilmeye hazır kutu yemekleri,

- kahve kremasi,

- $\quad$ enerji içecekleri,

- Öksürük şurupları, dekonjestan damlalarıdır.

\section{IV-YFMŞ ve ABD / Avrupa Ülkeleri}

Dünyanın en büyük YFMŞ üretici ve tüketicisi ABD'dir. ${ }^{26}$ ABD'de YFMŞ 1970'li yıllarda piyasaya çıkarılmış olup, 1970-2000 yılları arasında HCFS tüketimi yaklaşık \%1000 artmış, sakkaroz tüketimi \%50 azalmış, yiyecek ve içeçeklerdeki tüm tatlandırıcıların \%40’ını ve alkolsüz içeceklerdeki tatlandırıcıların \%100'e yakınını HCFS oluşturmuştur. $^{2}$

ABD'de YFMŞ tüketiminin artışında iki önemli etken mevcut olup, birincisi şeker ithalat kotaları ( ki bu şeker fiyatlarında artışa neden olmuştur) ikincisi de yerli mısır üretimi için devletin yapmış olduğu destektir. ${ }^{36}$

AB'de ilk olarak 1968 yılında başlamış olan şeker kamışı ve YFMŞ limitlerini belirleyen şeker kotası, 30.09.2017 tarihinde kaldırılmıştır. Şeker kotasının kaldırılma sürecindeki en büyük adım ise 2006 yılında gerçekleşen reform ve yeniden yapılanma sürecidir. ${ }^{24}$ Avrupa ülkelerinde YFMŞ üretim yüzdeleri şekil 1'de gösterilmektedir.

2015 yılında yayımlanan AB Tarım Hedef Raporuna göre YFMŞ, şeker kotasının kaldırılmasından önceki dönemde tatlandırıcı piyasasının \%4'ünden azını oluşturacak şekilde sınırlandırılmışken, kotanın kalkmasıyla birlikte 2025 
yılında AB’nin tatlandırıcı pazarının \%11'ini oluşturacağı tahmin edilmektedir. ${ }^{37}$

Goran ve ark.'nın 43 ülkede kişi başı tüketilen HCFS miktarının analizini yaptıkları bir araştırmada ABD yıllık kişi başına 24.78/kg ile 43 ülke arasında ilk sırada yer almıştır. Aynı çalışmada Avrupa'da kişi başı YFMŞ tüketim oranlarının, tüm tüketimin 1/3'ü kadarı olduğu gösterilmiştir. ${ }^{5}$

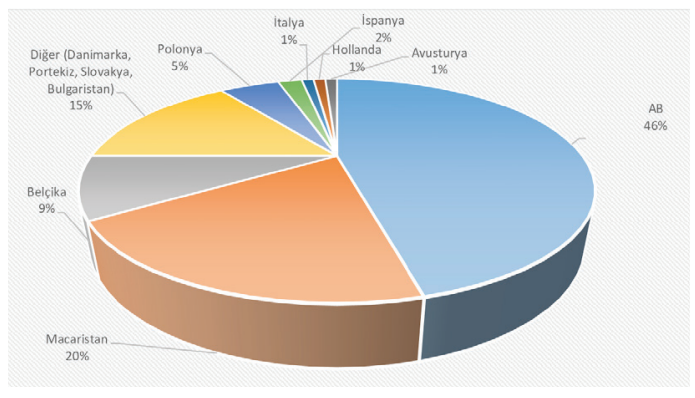

ISO Quarterly Market Outlook Şubat $2019^{24}$

Şekil 1. Avrupa ülkelerinde Yüksek Fruktozlu Mısır Şurubu üretim yüzdeleri ${ }^{38}$

\section{V-YFMŞ- Türkiye}

Türkiye'de halen geçerli olan şeker kanunu 19 Nisan 2001 tarihinde yürülüğe girmiştir. ${ }^{24}$ Türkiye’de sakkaroz kökenli ve nişasta kökenli olmak üzere iki tür şeker üretimi mevcuttur. Sakkaroz kökenli olarak pancar şekeri üretimi yapılırken, nişasta kökenli olarak glukoz şurubu, YFMŞ ve kristal fruktoz üretimi yapılmaktadır. Türkiye'de YFMŞ üretim kapasitesine sahip 5 adet nişasta bazlı şeker üreticisi şirket bulunmaktadır ve bu şirketlerin toplam kapasitesi 990.000 tondur. Ayrıca kota hakkı olmayan, ihraç amaçlı üretim yapan 5 adet daha YFMŞ üretim kapasitesine sahip nişasta bazlı şeker üretim şirketi bulunmaktadır ve toplam kapasiteleri 350.000 tondur. $^{24}$

4634 sayılı Şeker Kanunu kapsamında Bakanlar Kurulu tarafından belirlenen karar neticesinde Türkiye'nin yıllık şeker ihtiyacının \%95'nin pancar şekeri, \%5'nin nişasta bazlı şekerden karşılanması kararlaştırılmış ve Türkiyenin daha önce \%10 olan YFMŞ kotasının hükümet tarafından \%5’e düşürülmesiyle birlikte 2017 yılında 267.000 tonluk kota,
2018 yılında 133.500 ton olarak belirlenmiștir. ${ }^{24}$ Türkiye'de nişasta bazlı şekerin kotasının düşürülmesi ve vergi zamlarına rağmen YFMŞ tüketimi yüksektir. ${ }^{39}$ Goran ve ark.'nın 43 ülkede kişi başı tüketilen HCFS miktarının analizini yaptıkları çalışmada Türkiye kişi başı yıllık 4.20/kg ile 43 ülke arasında 11. sırada yer almıştır. ${ }^{5}$

\section{VI-YFMŞ ve OLUMSUZ SAĞLIK SONUÇLARI}

\section{YFMŞ- Obezite ve Metabolik Sendrom}

YFMŞ'e gelen eleştirilerin başında kilo alımı ve obeziteye neden olabileceği görüşü gelmektedir. Yapılan çalışmalarda YFMŞ ile tatlandırılmış gıdaların, açlık hissini artırıp, tokluk hissini azalttığı ve tatlılık seviyesi yüksek olduğu içinde tüketim amacıyla kişiler tarafından daha çok tercih edilebileceğini belirtmiştir. ${ }^{40}$ Bray ve ark.'1 batı ülkelerinde 1970’li yıllarda $0.5 \mathrm{~kg} / \mathrm{kişi} \mathrm{olan} \mathrm{YFMŞ} \mathrm{tüketiminin,}$ 2000 ’li yıllarda 35kg/kişi miktarına ulaştığını ve o tarihten günümüze geçen süreçte diyabet ve obezite sıklığındaki artışın paralellik gösterdiğini ileri sürmüştür. ${ }^{2}$

Metabolizmada glukoz stimülasyonu ile salınan insülin, leptin (tokluk hormonu) hormonunun salınımını uyarır ve ghrelin hormonunun (açlık hormonu) salınımını baskılar. Sonuç olarak, tokluk merkezi uyarılır ve yeme davranışını sona erdirir. Öte yandan fruktoz insülin salınımını uyarmadığı için leptin salgılanmaz ve tokluk hissi sağlanmadığı için kişi yemek yemeye devam eder ve bu sirkülasyonunda obeziteyi tetiklediği iddia edilir. ${ }^{41}$

Bunun yanında YFMŞ’nin obezite prevalansını artırdığ1 görüşüne katılmayan bir çok çalışma mevcuttur. Örneğin Le ve ark.'1 sağlıklı insanlara 4 hafta boyunca günlük $1.5 \mathrm{gr} / \mathrm{kg}$ fruktoz içeren bir diyet uygulamışlar ve sonuçta vücut ağırlığında, kas ve karaciğer lipit içeriğinde, değişiklik olmadığını, yalnızca plazma trigliserit (TG) ve glukoz seviyelerinin arttığını göstermişlerdir. ${ }^{42}$ Melanson ve ark.'ı yaptıkları randomize bir çalışmada bir grup kadına diyetinin \%30’unu karşılayacak şekilde sakkaroz, bir grup kadına YFMŞ vermişler ve iki grubun metabolik yanıtları arasında fark olmadığını ileri sürmüşlerdir. ${ }^{43}$ Soenen ve 
ark.'1, YFMŞ ile tatlandırılmış içeceklerin, süt ve sakkaroz içeren içeceklerle aynı doygunluk hissini oluşturduğunu iddia etmişlerdir. ${ }^{44}$ Angepolus ve ark.'1 2016 yılında yayınladıkları randomize çift kör paralel grup çalışmasında, Vücut Kitle İndeksleri (VKİ) 23-35 kg/m² olan 267 birey 4 gruba ayrılmış, gruplar 10 hafta boyunca YFMŞ, sakkaroz, glukoz ve fruktoz tüketmişler ve sonuçta gruplar arasında minimal bir fark olduğu, bu sonucun karışık ve klinik olarak anlamlı olmadığını belirtmişlerdir. ${ }^{45}$

Genel olarak bu çalışmalarda obezitenin sedece beslenmeyle değil, genetik ve çevresel faktörlerle de bağlantısı olduğu görüşü belirtilmiştir. Ayrıca YFMŞ kullanımının sınırlandırıldığı ülkelerde de obezite prevalansının yüksek seyretmesi soru işaretlerine neden olmaktadır. ${ }^{46}$ Ancak bu çalışmaların bir kısmının, çalışmalarda tatlandırıcı endüstrisinden mali destek aldıkları için eleştirilen çalışmalar olduğu ileri sürülmüştür. ${ }^{10}$

YFMŞ’nin bir diğer oluşturabileceği iddia edilen sağlık sorunu metabolik sendromdur. Metabolik sendrom; abdominal obezite, aterojenik dislipidemi [yüksek TG ve Yüksek Low-Density Lipoprotein (LDL), düşük High-Density Lipoprotein (HDL) düzeyleri], yüksek kan basıncı, insülin direnci, protrombik ve proenflamatuvar proçes ile karakterize multisistemik bir hastalıktır. ${ }^{47}$

Yüksek fruktoz alımı ile ilgili yapılan hayvan ve insan çalışmalarında yüksek fruktoz alımı ile obezite ve metabolik Sendrom arasında arasında ilişki bulunmuştur. ${ }^{10}$ Ayrıca meyvelerdeki doğal fruktozda bu etkilerin görülme olasılığının daha düşük olduğu ileri sürülmüştür.48

Bir çok hayvan model çalışmasında yüksek fruktoz içeren gıdaların aşırı tüketiminin toplam enerji alımı, insülin direnci, kilo alımı, dislipidemi ile ilişkisi olduğu gösterilmiştir. ${ }^{49}$ Bocarsyl ve ark.'larının yapmış olduğu hayvan model çalışmasında YFMŞ ile beslenen farelerde kontrol grubuna göre kilo, yağ ve TG seviyelerinde artış olduğu görülmüştür. ${ }^{13}$
İnsanlarda da yüksek fruktoz tüketiminin, artan kalori ve kilo alımı, hepatik ve yağ dokuda insülin direnci, dislipidemiyle ilişkisi bulunmuştur. ${ }^{48,49}$ Bazı çalışmalarda YFMŞ’nin içeriğindeki fruktozun insülin direnci ve non alkolik hepatosteatozu indükleme etkisinin enerji alımından bağımsız olduğu ileri sürülmüştür. ${ }^{11}$

\section{YFMŞ ve Tip 2 Diyabet}

Diyabet; kalp dokusunda, kan damarlarında, gözlerde, böbreklerde ve sinir sisteminde zaman ilerledikçe ciddi hasara yol açabilen, yüksek kan şekeri düzeyleri ile kendini gösteren kronik, metabolik bir hastalıktır. ${ }^{50}$ En yaygın olan diyabet türü, genellikle yetişkinlerde, vücutta insüline karşı direnç geliştiğinde ya da yeterli insülin yapılamadığında ortaya çıan tip 2 diyabettir ve son otuz yılda, tip 2 diyabet prevalansı gelir düzeyi farkı gözetmeksizin çoğu ülkede önemli ölçüde artmıştır. ${ }^{50}$

Bir monosakkarit olan fruktozun insülin direncindeki etki mekanizması glukozdan daha farklıdır. ${ }^{14}$ Fruktoz, yağ dokusundan leptin üretimini uyarmadığı ve insülin salınımı artırmadığı için direkt kilo alınmasına neden olabilir. ${ }^{48}$ Düzenli olarak aşırı fruktoz tüketmek vücutta insülinin etkilerine karşı direnç gelişimine yol açabilir ve beraberinde vücudun kan şekerini kontrol etme yeteneği azalarak bir süre sonra kanda insülin ve şeker seviyesinin artmaya başladığı görülür. ${ }^{51}$

Goran ve ark.'ları yaptıkları bir çalışmanın sonucunda YFMŞ’nin kilo aldırcı etkisinden bağımsız olarak tip 2 diyabet riskini artırdığını ileri sürmüşlerdir. ${ }^{5}$ İmamura ve ark.'ları şekerle tatlandırılmış içecek tüketiminin 10 yıllık süre zarfında ABD'de yaklaşık 10 milyon, İngiltere'de 80.000 tip 2 diyabet vakasına neden olabileceğini ileri sürmüşlerdir. ${ }^{52}$ Lin ve ark.'ları YFMŞ ve yüksek miktarda fruktoz tüketiminin obezite, koroner arter hastalığı, plazma TG yüksekliği, insülin direnci gibi olumsuz sağlık sonuçlarına neden olabileceği konusuna işaret etmişlerdir. ${ }^{53}$ 


\section{YFMŞ ve Kardiyovasküler Hastalıklar}

Kardiyovasküler hastalıklar $(\mathrm{KVH})$ dünya genelinde bir numaralı ölüm nedenidir ve her yıl tahmini olarak 17.9 milyon kişinin hayatını kaybetmesine neden olmaktadır. ${ }^{54}$ KVH'lar için risk faktörleri arasında obezite, hipertansiyon, abdominal yağlanma, dislipidemi, hiperglisemi gibi metabolik sendromun alt bileşenlerinin yanı sıra beslenme tarzı da önemli bir yer tutmaktadır. ${ }^{45}$

KVH'lar ve yüksek miktarda fruktoz içeren YFMŞ arasındaki ilişkiye odaklanan çok sayıda çalışma mevcuttur. Bu çalışmaların bir kısmı tutarlı bulgulara ulaştıklarını iddia eden çalışmalar olmakla birlikte, çoğu çalışma yazarı aralarındaki ilişkiyi doğrulayacak ileriye dönük biyokimyasal ve klinik araştırmalara ihtiyaç olduğunu belirtmişlerdir. ${ }^{55-58}$

\section{YFMŞ ve Kanser}

Bilindiği üzere obezite; kalp hastalıkları, hipertansiyon, eklem dejenerasyonları, tip 2 diyabet ve meme, kolon, rahim, böbrek ve özefagus kanserleriyle ilişkilidir. Özellikle kadınlarda kolorektal, meme ve endometriyum kanseri gelişiminde obezite önemli bir risk faktörüdür. 18 yaşından sonra en az 20 kilo alan kadınlar için meme kanseri gelişme riskinin 2 kat arttığı bilinmektedir. ${ }^{59}$

Mueller ve ark.'nın şekerle tatlandırılmış alkolsüz içecek tüketimiyle, Çin'li erkek ve kadınlarda pankreas kanseri arasındaki ilişkiyi araştırdıkları 60.524 katılımcıdan oluşan kohort çalışmalarının neticesinde, karıştırcı faktörlerin etkileri düzenlendikten sonra haftada 2 ve üstü alkolsüz içecek tüketen kişilerde, alkolsüz içecek tüketmeyen kişilere göre istatistiksel olarak anlamlı bir pankreas kanser riski olduğunu belirtmişlerdir. ${ }^{60}$

Kolorektal kanser gelişimine yatkın olan adenomatöz polipozis colisi olan mutant fareler üzerinde yapılan bir çalışmada YFMŞ verilen farelerde obezite ve metabolik sendrom yokluğunda tümör boyutu ve derecesinde artış olduğu gösterilmiştir. ${ }^{61}$
Yüksek fruktozlu bir diyetin, hepatosellüler karsinomu etkileme durumunun incelendiği bir hayvan model çalışmasında, 8 hafta boyunca dietilnitrozaminle hepatokarsinogenez açısından indüklenen sıçanlara normal diyet, yağlı diyet ve yüksek fruktozlu diyet uygulanmış ve diyetteki yağdan ziyade, fruktozun insülin direnci ve oksidatif stres yoluyla prekanseröz hepatosit sayısında artış olduğu gösterilmiştir. ${ }^{62}$

\section{YFMŞ ve Astım}

Astım, tekrarlayan nefes darlığı ve öksürük ataklarıyla karakterize, her yaştan insanda görülebilen, özellikle çocukların en sık görülen kronik hastalıklarından biridir ve günümüzde yaklaşık 235 milyon insanı etkilediği tahmin edilmektedir. ${ }^{63}$ Literatürde YFMŞ kullanılarak hazırlanan gıda katkı maddelerinin astıma yol açabileceği görüşünü savunan çeşitli çalışmalar mevcuttur. Park ve ark.'1, ABD’nin 23 eyaletinde yapılan Davranışsal Risk Faktörü Gözetim Sistemi verilerini kullanarak yaptıkları bir çalışma analizinin sonucunda, obez olmayan yetişkinlerde şekerle tatlandırılmış içecek tüketimi ile astım arasında bir ilişki olduğu sonucuna varmışlardır. ${ }^{64}$

Fruktoz içeriği yüksek gıdaların astım üzerindeki etkisini incelemek amacıyla yapılan bir başka çalışmada, bir grup çocuğa tatlandırma amacıyla yüksek miktarda fruktoz içeren içecekler, yaş, cinsiyet, ırk, etnik köken, VKİ ve toplam enerji alımı bakımından eşleştirme yapılmış olan kontrol grubuna ise portakal suyu verilmiş ve sonuç olarak yüksek miktarda fruktoz içeren içecekleri tüketmenin 2-9 yaş arası çocuklarda astım ile anlamlı ilişkisi olduğu gösterilmiştir. ${ }^{65}$

\section{YFMŞ ve Nonalkolik Hepatosteatoz}

Nonalkolik hepatosteatoz, çocuk ve erişkinlerde en yaygın görülen kronik karaciğer hastalıklarından biridir. ${ }^{66} \mathrm{Ze}-$ minde yatan risk faktörleri arasında, insülin direnci, tip 2 diyabet, obezite, TG yüksekliği ve hipertansiyonu içeren metabolik sendrom yer almaktadır. ${ }^{67}$ 
Literatürde fruktozun metabolize olduğu tek organın karaciğer olması ve ayrıca glukoza göre daha hızlı çözünerek Very Low Density Lipoprotein ( VLDL), LDL gibi lipitlere dönüşüp, nonalkolik hepatasteatoza neden olabileceği ile ilgili çok sayıda çalışma mevcuttur. ${ }^{13,41,68}$

Mock ve ark.'ı yaptıkları deneysel hayvan modeli çalışmasında 4 gruba ayırdıkları sıçanlara 8 hafta boyunca su, YFMŞ-55, fruktoz ve sakkaroz ile tatlandırılmış içecek vererek sonuçları değerlendirmişler ve YFMŞ -55 verilen grupta karaciğerdeki yağ infiltrasyonunun diğer 3 gruba göre anlamlı olarak yüksek olduğunu göstermişlerdir. $(\mathrm{p}=0.03)^{69}$

\section{YFMŞ ve Gut}

Gut, vücutta ürik asit miktarının artmasıyla paralel olarak, eklemlerde, vücut sıvılarında ve dokularda ürik asit kristalleri (monosodyum ürat) birikimiyle ortaya çıkan ağrılı, genelde tek atakta bir eklemi etkileyen ( sıklıkla ayak baş parmağını) inflamatuar bir artrit türüdür. ${ }^{70}$

Aşırı fruktoz tüketiminin inflamasyonu ve ürik asit üretimini artırarak gut hastalığını şiddetlendirebileceği ileri sürülmektedir. ${ }^{71}$ Nguyen ve ark.'ları 4867 adelosanla yapmış oldukları kesitsel türde epidemiyolojik çalışmanın sonucunda, şekerle tatlandırılmış içecek tüketimiyle yüksek serum ürik asit seviyeleri arasında istatistiksel olarak anlamlı bir ilişki bulmuşlardır $(\mathrm{p}=0.01) 72 \mathrm{Bu}$ çalışmaların yanı sıra tersini iddia eden çalışmalarda mevcuttur. Wang ve ark.'1 yaptıkları çalışmaların neticesinde fruktoz alımı ile serum ürik asit seviyeleri arasında ilişki olmadığını ileri sürmüşlerdir. ${ }^{73}$

\section{YFMŞ ve Diş Çürükleri}

Diş çürügü, dünya çapında önemli bir halk sağlığı sorunudur. Şeker içermeyen beslenme alışkanlığı gibi basit bireysel müdahalelerle önlenebilen diş çürüklerinin tedavisi maliyetlidir. $^{74}$

Aşırı şeker tüketiminin diş minesi üzerindeki olumsuz etkileri aşikardır. YFMŞ, içeriğindeki yüksek miktardaki fruktozun kan konsantrasyonundaki yoğun dalgalanmalarından dolayı, diş minesinden daha fazla miktarda mineral çekilmesine yol açarak, diş çürüklerine zemin hazırlayabileceği ileri sürülmüştür. ${ }^{75}$

\section{YFMŞ ve Civa Kontaminasyonu}

Civa en güçlü nörotoksik ajanlardan biridir ve aynı zamanda YFMŞ üretiminde kullanılan kostik sodanın yapısında da bulunmaktadır. ${ }^{75}$ Dufault 2009 yılında YFMŞ’nin üretim aşamasında, YFMŞ’nin antimikrobiyal amaçla kullanılan civa metalini içerip içermediğini araştırmak için bir pilot çalışma yapmış olup çalışmasında 3 farklı üretici tarafından piyasaya sürülen YFMŞ katkı maddesi içeren gıdaları analiz etmiş ve 1gr YFMŞ başına 0.005-0.570 mikrogram civa tespit etmiştir. ${ }^{76}$ Amerika Birleşik Devletlerinde kişi başı YFMŞ tüketiminin ortalama 50 gr olduğu hesaba katıldığında vücuda alınan civa miktarının olası olumsuz etkilerinin göz önünde bulunulması gerektiği vurgulanmıştır. ${ }^{76}$

\section{TARTIŞMA}

YFMŞ günümüzün önemli bir halk sağlığı sorunudur ve son yıllarda üzerinde bir hayli konuşulan ve tartışılan g1da katkı maddelerinden biridir. YFMŞ, günümüzde günlük olarak tükettiğimiz bir çok gıda maddesinde sıklıkla kullanılan kalorili tatlandırıcı maddelerinden biri olarak yerini almıştır. YFMŞ ile ilgili endişelerin ana kaynağı da içeriğindeki fruktozdan ileri gelmektedir.

Geçtiğimiz yüzyılda batı dünyasının bulaşıcı hastalıklarla mücadelesinde başarılı sonuçlar almasının ardından yeni mücadele hiperglisemi, hiperlipidemi, insülin direnci ve obezite gibi sağlık sorunları üzerinde yoğunlaşmaya başlamıştır. Bu durum özellikle diyette olan değişikliklerle korele olup, değişen diyetten kasıt, evde hazırlanan yemeklerin yerine kalorisi artmış, katkı maddeleri eklenmiş hazır gıda tüketiminin artmasıdır. ${ }^{20}$

Beslenme kılavuzları, içeriği ne olursa olsun ilave kalorili 
tatlandırıcıların tüketimine sınırlama getirilmesini önermektedir. Amerikalılar için Diyet Kılavuzu 2015-2020 ve DSÖ’ye göre, aşırı kilo alımını önlemek için serbest şeker alımının günlük alınan kalorinin \%10’unu geçmemesini önermektedir (ortalama 2000 kalorilik bir diyette)..$^{22,77}$

YFMŞ’ye gelen eleştirilerin başında kilo alımı ve obezite gelmektedir. ${ }^{2}$ Bunun yanı sıra farklı sağlık sorunlarını da dile getiren çalışmalar mevcuttur. Bu çalışmalarda, YFMŞ tüketimine bağlı olarak vücuda alınan fruktozun metabolik etkileri neticesinde, hiperlipidemi, insülin direnci, nonalkolik hepatostatoz, KVH, kanser, astım, gutta alevlenme, tip 2 diyabet gelişebileceği iddia edilmiştir. 5,60,64,69,71

YFMŞ üzerine yapılan tartışma konulardan bir diğeri de etiketlerde belirtilen şeker oranlarındaki belirsizlikle ilgilidir. Gıda etiketlerinde şekerler karbonhidratlar adı altında gram cinsinden ifade edilir. Gıda etiketlerinde içeriğindeki şeker miktarının gram olarak belirtilmesi zorunluluğu olmasına rağmen şekerin türünün (glukoz, fruktoz....gibi) miktarı etikette açıklanmadığı ve etiketteki içerik listesinde YFMŞ yazılmış olsa bile hangi YFMŞ formulasyonunun kullanıldığının belirtilmesi zorunluluğu olmadığı için ürünlerdeki fruktoz miktarı net olarak bilinmemektedir. ${ }^{8,78}$

Günümüzde özellikle içeceklerdeki fruktoz düzeylerinin, üreticilerin iddia ettikleri miktardan daha yüksek olduğu konusu gündemdedir. Jeong ve rakadaşları 2017 yılında Yüksek Performanslı Sıvı Kategorisi (High Performance Liquid Chromatography -HPLC) yöntemini kullanarak çeşitli süt ürünlerindeki fruktoz ve glukoz miktarlarını analiz etmişler ve hem etikette yazan karbonhidrat türünün hem de miktarının, yaptıkları analiz sonucuyla tutarlı olmadığını göstermişleridir. ${ }^{79}$

Ventura ve arkadaşları yaptıkları bir çalışmada 23 popüler şekerle tatlandırılmış içeceklerdeki fruktoz oranlarına bakmışlar ve bazı ünlü markalarda \%55 yerine \%65 fruktoz içeriği olan YFMŞ’nin kullanıldığını belirtmişlerdir. ${ }^{78}$
Walker va ark.'ı tarafından yapılan bir başka çalışmada, şekerle tatlandırılmış içeceklerin, birbirinden bağımsız laboratuvarlarda yapılan analiz sonuçlarında beklenenden daha fazla fruktoz konsantrasyonu saptanmıştır. ${ }^{80}$

Üreticilerin gıdalardaki katkı maddelerinin miktarı ile ilgili tüketicilere sundukları bilgilerdeki eksiklik ve üründeki YFMŞ miktarının ölçülmesindeki zorluklardan dolayı kamuya açık çok az veri vardır ve bu kısıtlı verilerde daha çok uluslararası şeker ve tatlandırıcı raporları ve AB ülkeleri için belirlenmiş olan kotalardır. ${ }^{8,81}$

YFMŞ içeren ürünlerin düzenlemelerinin ülkeler arasında farklılık göstermesi ve piyasada fruktoz konsantrasyonları farklı ürünlerin olması, bireylerin tükettikleri YFMŞ miktarının doğru bir şekilde ölçülememesine ve bunun neticesinde YFMŞ’nin sağlık üzerindeki etkilerini değerlendirmekte zorluklara neden olmaktadır. ${ }^{8,10}$

Bir taraftan olumsuz sağlık sonuçlarına neden olduğunu belirten çalışmalar, bir taraftan YFMŞ ile olumsuz sağlık sonuçları arasındaki ilişkinin klinik olarak anlamlı olmadığını belirten çalışmalar, öte yandan FDA'nın YFMŞ’yi "Genel olarak güvenli" kategorisine alması kafalarda hala soru işaretlerine neden olmaktadır. YFMŞ için, uzun vadeli, farklı toplumları içeren, tarafsız olması açısından gıda endüstrisinden destek alınmadan yapılması gereken çalışmalara gereksinim vardır. Belki bu çalışmalar sonucunda etiketlere yansıyan miktar ve şeker türleri ile ilgili bilgilerin doğru verilmesi zorunluluğu ortaya çıkabilir.

YFMŞ, kalori değeri yüksek, besin değeri düşük bir gıda katkı maddesidir. Bu bağlamda YFMŞ içeren gıda maddelerinden uzak kalabilmek için, meyveleri doğal halleriyle tüketmek, gıda maddelerini satın almadan önce etiketlerini incelemek ve YFMŞ ya da sakkaroz gibi şeker içeren gıdaları almaktan kaçınmak önerilebilecekler arasındadır.

Yaşam tarzının yıllara göre değişmesi; örneğin daha fazla araba kullanmak, daha fazla televizyon karşısında vakit 
geçirmek, daha fazla masa başı çalışmak, daha fazla karbonhidrat içeren gıda maddeleri tüketmek ..... ve sonuçta alınan ve harcanan kalori arasındaki dengesizlik, kilo al1$\mathrm{ml}$, obezite ve beraberinde getirdiği sağlı sorunları için yadsınmaz bir gerçektir. Bu sebeple obezite ve diğer sağlık sorunlarından kaçınmak için tükettiğimiz gıda maddelerine dikkat etmemiz ve beraberinde yaşam tarzımızı da gözden geçirmemiz gerekmektedir.

Sonuç olarak YFMŞ’nin sağlık açısından olumsuz etkileri, içeriğindeki fruktoza atfedilen obezite, KVH'lar, metabolik sendromdaki olası rolü, YFMŞ’nin üretim aşamasındaki civa kontaminasyonu ve gıda etiketleriyle gıdanın içeriğindeki YFMŞ miktarı arasındaki tutarsızlıklar üzerinde yoğunlaşmıştır. YFMŞ gibi şeker içerikli gıda maddelerinin sınırlı tüketimi konusunda tüketicileri bilinçlendirmek, tüketim hızını azaltmak için vergilendirmeyi artırmak, üreticilerin YFMŞ içeriği açısından tüketicilere doğru bilgi sunabilmeleri için tutarlı etiketleme yapmalarını sağlamak ve YFMŞ’nin insan metabolizması üzerindeki etkilerinin daha iyi anlaşılabilmesi için tarafsız, ileriye dönük biyokimyasal ve klinik çalışmaların yapılması bu olumsuzlukların önlenebilmesi adına yapılacak halk sağlığı stratejileri arasında olmalıdır. 
Sakarya Tıp Dergisi 2020;10(Özel Sayı):57-68

AŞıCI ve Ark., Geçmișten Günümüze Yüksek Fruktozlu Mısır Şurubu ve Sağılk Etkileri

\section{Kaynaklar}

1. Ruiz-Matute AI, Weiss M, Sammataro D, Finely J, Sanz ML. Carbohydrate Composition of High-Fructose Corn Syrups (HFCS) Used for Bee Feeding: Effect on Honey Composition. J. Agric. Food Chem 2010; 58(12): 7317-7322

2. Bray GA, Nielsen SJ, Popkin BM. Consumption of High-Fructose Corn Syrup in Beverages may Play a Role in the Epidemic Of Obesity. Am J Clin Nutr 2004;79(4):537-43.

3. Karaoğlu MM. Yüksek Fruktozlu Mısır Şurubu. Gida Mühendisliği Dergisi 2011;33.

4. Bode JW, Empie MW, Brenner KD. Evolution of High Fructose Corn Syrup Within the Sweeteners Industry. J.M. Rippe (ed.), Fructose, High Fructose Corn Syrup, Sucrose and Health, Nutrition and Health, Chapter 9, ISBN 978-1-4899-8076-2 ISBN 978-1-4899-8077-9 (eBook) DOI 10.1007/978-1-4899-8077-9 Springer New York Heidelberg Dordrecht London, ( Springer Science+Business Media New York ;2014.p.137-148.

5. Goran MI, Ulijaszek S, Ventura E. High Fructose Corn Syrup and Diabetes Prevalence: A global perspective. Global Public Health 2013;8(1):55-64.

6. Heiss SN, Bates BR. When a Spoonful of Fallacies Helps the Sweetener Go Down: The Corn Refiner Association's Use of Straw-Person Arguments in Health Debates Surrounding High-Fructose Corn Syrup. Health Communication 2016;31(8): 1029-35.

7. https://www.persistencemarketresearch.com/market-research/high-fructose-corn-syrup-hfcs-market.asp (Erişim Tarihi: 10.5.2020)

8. https://ec.europa.eu/health/sites/health/files/nutrition_physical_activity/docs/2019_sciview_b3_sr_en.pdf (Erişim Tarihi: 10.5.2020).

9. Dillen, K., Dries L, Tolens E. The mpact of the EU sugar reform on sugar and sugar substitute industries. Working Paper, $n^{\circ}$ 97, Centre for Agricultural and Food Economics, Katholieke Universiteit Leuven, 2006

10. https://www.ama-assn.org/sites/ama-assn.org/files/corp/media-browser/public/about-ama/councils/Council\%20Reports/council-on-science-public-health/a08-csaph-high-fructose-syrup.pdf (Erișim Tarihi: 10.5.2020).

11. Lanaspa MA, Ishimoto T, Li N, Cicerchi C, Orlicky DJ, Ruzicky P, et al. Endogenous Fructose Production and Metabolism in the Liver Contributes to the Development of Metabolic Syndrome. Nat Commun 2013;4 (Article Number:2434); 1-8.

12. G Ang BR, Yu GF. The Role of Fructose in Type 2 Diabetes and Other Metabolic Diseases. J Nutr Food Sci 2018;8(1):1-4

13. Bocarsly ME, Powell ES, Avena NM, Hoebel BG. High-fructose corn syrup causes characteristics of obesity in rats: Increased body weight, body fat and triglyceride levels. Pharmacology, Biochemistry and Behavior 2010;97(1):101-6.

14. Sundborn G, Thornley S, Merriman T, Lang B, King C, Lanaspa MA, et al. Are Liquid Sugars Different from Solid Sugar in Their Ability to Cause Metabolic Syndrome? Obesity 2019;27(6):879-887.

15. https://corn.org/about-cra/faq/\#HFCS (Erişim Tarihi: 10.4.2020).

16. https://www.medscape.com/answers/2087913-163743/what-is-glucose (Erişim Tarihi: 10.4.2020).

17. Yerlikaya A, Dagel T, King C, Kuwabara M, Lanaspa MA, Andres Hernando A, et al. Dietary and commercialized fructose: Sweet or sour? Int Urol Nephrol 2017; 49(9):1611-1620.

18. https://www.sciencedirect.com/topics/agricultural-and-biological-sciences/sweetness (Erișim Tarihi: 10.4.2020).

19. Zargaraan A, Kamaliroosta L, Yaghoubi AS, Mirmoghtadaie L . Effect of Substitution of Sugar by High Fructose Corn Syrup on the Physicochemical Properties of Bakery and Dairy Products: A Review. Nutrition and Food Sciences Research 2016;3(4): 3-11.

20. Strober JW, Brady MJ. Dietary Fructose Consumption and Triple-Negative Breast Cancer Incidance. Front Endocrinol (Lausanne) 2019;10(Article367):1-7.

21. Aguirre EK, Mytton OT, Monsivais P. senior university lecturer. Liberalising agricultural policy for sugar in Europe risks damaging public health. BMJ 2015;351:h5085.

22. https://www.who.int/publications/i/item/9789241549028 (Erişim Tarihi: 10.4.2020).

23. https://www.berkeleywellness.com/healthy-eating/nutrition/article/high-fructose-corn-syrup-worse-regular-sugar (Erişim Tarihi: 10.4.2020).

24. https://www.turkseker.gov.tr/SECTOR_REPORT.pdf) (Erişim Tarihi: 12.4.2020).

25. Kroger M, Meister K, Kava R. Low-calorie Sweeteners and Other Sugar Substitutes: A Review of the Safety Issues. Comprehensive Reviews in Food Science And Food Safety.2006;5:35-47.

26. Parker K, Salas M and Nwosu VC. High fructose corn syrup: Production, uses and public health concerns. Biotechnology and Molecular Biology Review 2010; 5(5):71 - 78.

27. Pepin A, Stanhope KL, Imbeult P. Are Fruit Juices Healthier Than Sugar-Sweetened Beverages? A Review. Nutrients 2019; 11(5):1006.

28. Alibekov RS, Kaiypova AB, Urazbayeva KA, Ortayev AE, Abdugani M. Effect of Substitution of Sugar by High Fructose Corn Syrup of the Confiture on the base of Physalis. Periódico Tchê Química 2019; 16:688-697.
29. Özcan S. Modern Dünyanın Vazgeçilmez Bitkisi Mısır: Genetiği Değı̌sștirilmiș (Transgenik) Mistrn Tartmsal Üretime Katkist. Türk Bilimsel Derlemeler Dergisi 2009; 2(2): 1-34.

30. https://www.healthline.com/nutrition/high-fructose-corn-syrup-vs-sugar\#production Erişsim Tarihi: 12.4.2020).

31. Forshee RA, Storey ML, Allison DB, Glïnsmann WH, Heİn GL, Lİneback DR, et al. A Critical Examination of the Evidence Relating High Fructose Corn Syrup and Weight Gain. Critical Reviews in Food Science and Nutrition 2007:47(6):561-582.

32. Johnson RJ, Segal MS, Sautin Y, Nakagawa T, Feig DI, Kang DH, et al. Potential role of sugar (fructose) in the epidemic of hypertension, obesity and the metabolic syndrome, diabetes, kidney disease, and cardiovascular disease. Am J Clin Nutr 2007;86(4):899-906.

33. Moeller SM, Fryhofer SA, Osbahr III AJ, Robinowitz CB \& for the Council on Science and Public Health, American Medical Association. The Effects of High Fructose Syrup. Journal of the American College of Nutrition 2009;28 (6):619-626.

34. Kaplan Bulut İ, Mir S. Fruktoz ve böbrek hastalikları. Cumhuriyet Tip Dergisi 2011;33(4):499-507.

35. Carvalho CT, Souza MZ, Arbex N, Sa D, Rodrigues LC, Rocha de Sa DA, et al. The Role of Fructose in Public Health and Obesity. Health 2018; 10(4): 434-41.

36. Dilk A, Savaiano DA. Sugar Price Supports and Taxation. A Public Health Policy Paradox. Nutrition Today 2017;52(3):143-150

37. https://ec.europa.eu/info/sites/info/files/food-farming-fisheries/farming/documents/agricultural-outlook-report-2015_en.pdf (Erişim Tarihi: 12.4.2020).

38. https://www.isosugar.org/publication/143/quarterly-market-outlook---february-2019 (Erișim Tarihi: 12.4.2020).

39. Arslan Y. Exploring The Effects Of Consumers' Nutritional Knowledge and Information Interest on the Acceptance of Artificial Sweetener Usage In Soft Drinks. Marketing and Management of Innovations 2019:3;33-44.

40. Vartanian LR, Schwartz MB, Brownell KD. Effects of Soft Drink Consumption on Nutrition and Health: A Systematic Review and Meta-Analysis. Am J Public Health 2007;97(4):667675 .

41. https://www.saglik.gov.tr/EN,32859/ministry-of-health-press-release-scientific-board-report-on-health-impact-of-starch-based-sugars-sbs.html (Erişim Tarihi: 10.4.2020).

42. Le, K A ; Faeh, D ; Stettler, $R$; Ith, $M$; Kreis, $R$; Vermathen, $P$; Boesch, $C$; Ravussin, E; Tappy, LA .4-wk high-fructose diet alters lipid metabolism without affecting insulin sensitivity or ectopic lipids in healthy humans. Am J Clin Nutr 2006;84:1374 -9.

43. Melanson KJ, Zukley L, Lowndes J, Nguyen V, Angelopoulos TJ, Rippe JM. Effects of high-fructose corn syrup and sucrose consumption on circulating glucose, insulin, leptin, and ghrelin and on appetite in normal-weight women. Nutrition 2007; 23(2):103-112.

44. Soenen S, Westerterp-Plantenga MS. No differences in satiety or energy intake after high-fructose corn syrup, sucrose, or milk preloads. Am J Clin Nutr 2007;86(6):1586 -94.

45. Angelopoulos TJ, Lowndes J, Sinnett S, Rippe JM. Fructose Containing Sugars at Normal Levels of Consumption Do Not Effect Adversely Components of the Metabolic Syndrome and Risk Factors for Cardiovascular Disease. Nutrients 2016;8(4): 179 .

46. G Harvey Anderson. Much ado about high-fructose corn syrup in beverages: the meat of the matter. Am J Clin Nutr 2007;86:1577- 8

47. Executive Summary of The Third Report of The National Cholesterol Education Program (NCEP) Expert Panel on Detection, Evaluation, And Treatment of High Blood Cholesterol In Adults (Adult Treatment Panel III) JAMA 2001;16;285(19):2486-97.

48. Elliott SS, Keim N, Ster JS, Teff K, Havel PJ. Fructose, weight gain, and the insulin resistance syndrome. Am J Clin Nutr 2002;76(5):911-22.

49. Rutledge AC, Adeli K. Fructose and the Metabolic Syndrome: Pathophysiology and Molecular Mechanisms . Nutrition Reviews 2007; 65(6 Pt 2):13-23.

50. https://www.who.int/health-topics/diabetes\#tab=tab_1 (Erişim Tarihi: 10.4.2020).

51. Stanhope KL, Schwarz JM,Keim NL, Griffen SJ, Bremer AA, Graham JL. Consuming fructose-sweetened, not glucosesweetened, beverages increases visceral adiposity and lipids and decreases insulin sensitivity in overweight/obese humans. J Clin Invest 2009;119(5):132234.

52. Imamura F,O'Connor L, Ye Z, Mursu J, Hayashino Y, Bhupathiraju SN. Consumption of sugar sweetened beverages, artificially sweetened beverages, and fruit juice and incidence of type 2 diabetes: systematic review, meta-analysis, and estimation of population attributable fraction Br J Sports Med 2016;50:496-504.

53. Lin WT, Chan TF, Huang HL, Lee CY, Tsai S, Wu PW, et al. Fructose-Rich Beverage Intake and Central Adiposity, Uric Acid, and Pediatric Insulin Resistance. The Journal of Pediatrics 2016;171:90-96.e1.

54. https://www.who.int/health-topics/cardiovascular-diseases/\#tab=tab_1 (Erişim Tarihi: 10.5.2020). 
Sakarya Tıp Dergisi 2020;10(Özel Sayı):57-68

AŞICI ve Ark., Geçmişten Günümüze Yüksek Fruktozlu Mısır Şurubu ve Sağlık Etkileri

55. Stanhope KL, Medici V, Bremer AA, Lee V, Lam HD, Nunez MV, et al. A Dose-Response Study Of Consuming High-Fructose Corn Syrup-Sweetened Beverages On Lipid/ Lipoprotein Risk Factors for Cardiovascular Disease in Young Adults. Am J Clin Nutr 2015;101(6):1144-54.

56. Stanhope KL, Bremer AA, Medici V, Nakajima K, Ito Y, Nakano T, et al. Consumption Of Fructose And High Fructose Corn Syrup Increase Postprandial Triglycerides, LDL-Cholesterol, And Apolipoprotein-B In Young Men And Women. J Clin Endocrinol Metab 2011;96(10):1596-605.

57. Sadowska J, Bruszkowska M. Comparing The Effects Of Sucrose And High-Fructose Corn Syrup On Lipıd Metabolism And The Risk OfCardiovascular Disease In Male Rats. Acta Sci Pol Technol Aliment 2017;16(2):231-240.

58. De Koning L., Malik, VS., Kellogg MD, Rimm EB., Willett WC, Hu FB. Sweetened Beverage Consumption, Incident Coronary Heart Disease, and Biomarkers of Risk in Men. Circulation 2012;125(14):1735-41,

59. Ross SM. Sugary Drinks A Modifiable Risk Factor for Cancer Prevention. Holist Nurs Pract 2019;33(6):366-369.

60. Mueller NT, Odegaard A, Anderson K, Yuan JM, Gross M, Koh WP, et al.Soft Drink and Juice Consumption and Risk of Pancreatic Cancer: The Singapore Chinese Health Study. Cancer Epidemiol Biomarkers Prev 2010; 19(2): 447-455.

61. Goncalves MD, Lu C, Tutnauer J, Hartman TE, Hwang SY, Murphy JC, et al. High-fructose corn syrup enhances intestinal tumor growth in mice. Science 2019;363(6433):1345-1349.

62. Kumamoto $R$, Uto H, Oda K, Ibusuki $R$, Tanoue S, Arima S, et al. Dietary fructose enhances the incidence of precancerous hepatocytes induced by administration of diethylnitrosamine in rat. European Journal of Medical Research 2013;18:54:1-8.

63. https://www.who.int/news-room/facts-in-pictures/detail/asthma) (Erișim Tarihi: 23.04.2020).

64. Park S, Akinbami LJ, McGuire LC, Blanck HM. Association of sugar-sweetened beverage intake frequency and asthma among U.S. adults, 2013. Preventive Medicine2016; 91: 58-61.

65. DeChristopher LR, Uribarri J, Tucker KL. Intakes of apple juice, fruit drinks and soda are associated with prevalent asthma in US children aged 2-9 years. Public Health Nutrition 2016; 19(1):123-130.

66. Vos MB, Lavine JE. Dietary Fructose in Nonalcoholic Fatty Liver Disease. Hepatology 2013;57(6):2525-31
67. Angulo P. Non-alcoholic fatty liver disease. N Engl J Med 2002; 346(16): 1221-31.

68. Hallfrisch, J. Metabolic effects of dietary fructose. The FASEB Journal 1990;4(9): 2652-60.

69. Mock K, Lateef S, Benedito VA, Toua JC. High-fructose corn syrup-55 consumption alters hepatic lipid metabolism and promotes triglyceride accumulation. Journal of Nutritional Biochemistry 2017;39:32-39.

70. https://www.cdc.gov/arthritis/basics/gout.html (Erişim Tarihi: 23.04.2020).

71. Choi HK, Curhan G. Soft drinks, fructose consumption, and the risk of gout in men: prospective cohort study. BMJ 2008;336(7639):309-312.

72. Nguyen S, MD, Choi HK, Lustig RH, Hsu C. Sugar-Sweetened Beverages, Serum Uric Acid, and Blood Pressure in Adolescents. The Journal of Pediatrics 2009;154(6):807-813.

73. Wang DD, Sievenpiper JL, de Souza RJ, Chiavaroli L, Ha V, Cozma AI, Mirrahimi A, et al. The Effects of Fructose Intake on Serum Uric Acid Vary among Controlled Dietary Trials. The Journal of Nutrition 2012;142(5):916-23

74. https://www.who.int/news-room/fact-sheets/detail/sugars-and-dental-caries (Erişim Tarihi: 23.04.2020).

75. Nithya S, Deepika A, Rehman A, Abineeshwar G. Potential metabolic effects with use of high-fructose corn syrup in foodstuffs: A review. Drug Invention 2019; 11(1): 156-159.

76. Dufault R, LeBlanc B, Schnoll R, Cornett C, Schweitze R, Wallinga D, Hightower J, et al. Mercury from chlor-alkali plants: measured concentrations in food product sugar. Environmental Health 2009; 8(2):1-6.

77. https://health.gov/sites/default/files/2019-09/2015-2020_Dietary_Guidelines.pdf (Erișim Tarihi: 23.04.2020).

78. Ventura EE, Davis JN, Goran MI. Sugar Content of Popular Sweetened Beverages Based on Objective Laboratory Analysis: Focus on Fructose Content. Obesity (Silver Spring) 2011;19(4):868-74.

79. Jeong D, Kim DH, Oh YT, Song KY, Kim HS, Jhon JW, et al. Fructose Contents of Various Popular Sweetened Beverages based on Milk Using by HPLC. J. Milk Sci.Biotechnol 2017;35(2):99-104.

80. Walker RW, Dumke KA, Goran MI. Fructose content in popular beverages made with and without high-fructose corn syrup. Nutrition 2014;30(7-8):928-35.

81. İçli N, Özkubat Çantay Ö. The Determination of Usage Prevalance of Corn Syrups in Processed Food Products in Turkey and Health Risks. ACU Sağllk Bil Derg 2019;10(1):78-83. 